\title{
Instruments of health literacy used in nursing studies with hypertensive elderly
}

\author{
Instrumentos de letramento em saúde utilizados nas \\ pesquisas de enfermagem com idosos hipertensos \\ Instrumentos para evaluar el letramiento \\ en salud de ancianos con hipertensión
}

\author{
Ana Larissa Gomes Machado ${ }^{a}$ \\ Francisca Elisângela Teixeira Lima ${ }^{b}$ \\ Tahissa Frota Cavalcante ${ }^{c}$ \\ Thelma Leite de Araújo ${ }^{d}$ \\ Neiva Francenely Cunha Vieirae
}

DOl: $\quad$ http://dx.doi.org/10.1590/19831447.2014.04.45139

\footnotetext{
${ }^{a}$ Nurse. PhD student in Nursing at the Postgraduate Program in Nursing at Universidade Federal do Ceará (UFC). Professor at Universidade Federal do Piaul (UFPI). Fellow of the Brazilian Coordination of Higher Education Personnel (CAPES). Fortaleza-Ceará (CE)/ Brazil.Email: analarissa2001@yahoo.com.br

${ }^{b}$ Nurse. PhD, Professor at the Department of Nursing of UFC. Fortaleza-CE, Brazil.Email: felisangela@yahoo.com.br

c Nurse. Professor, with postdoctoral degree, at Universidade da Integração Internacional da Lusofonia Afro-brasileira (UNILAB). Fortaleza-CE/Brazil. Email: tahissa@ig.com.br

${ }^{d}$ Nurse. PhD, Professor at the Department of Nursing of UFC. CNPq fellow (PQ1A). Fortaleza-CE, Brazil. Email: thelmaarauj02003@yahoo.com.br

e Nurse. Professor, with postdoctoral degree, of the Department of Nursing of UFC. CNPq fellow (PQ2). Fortaleza-CE, Brazil. Email: neivafrancenely@hotmail.com
}

\section{ABSTRACT}

This study aimed to analyze nursing research regarding the instruments used to evaluate health literacy in elderly hypertensive patients. This is an integrative literature review done in the databases LILACS, PubMed, CINAHL, Scopus, and Cochrane, in June 2013. The articles, electronically available, were selected for full-text review by nurses, who assessed health literacy of elderly with hypertension. Eight studies were selected for analysis and four different instruments were used in the research. The instruments were developed according to a methodology and they were all designed to evaluate the abilities of elderly regarding reading, numeracy, pronunciation and recognition of some health-related words. The nursing research analyzed in this study revealed the gaps in care related to measures aimed to increase patient's involvement in decision-making. Also, the instruments used for measuring health literacy showed limitations, and there is no gold standard test.

Descriptors: Elderly. Health literacy. Hypertension. Nursing research.

\section{RESUMO}

Objetivou-se analisar as pesquisas de enfermagem quanto aos instrumentos utilizados para avaliar o letramento em saúde de idosos hipertensos. Trata-se de uma revisão integrativa realizada nas bases de dados LILACS, PubMed, CINAHL, Scopus e Cochrane em junho de 2013, com artigos de pesquisa completos, realizados por enfermeiros, disponíveis eletronicamente e que avaliaram o letramento em saúde de idosos com hipertensão. Foram selecionados oito estudos para análise, e quatro instrumentos diferentes foram utilizados nas pesquisas. Os instrumentos resultaram de pesquisas metodológicas e apresentaram em comum a avaliação da habilidade do idoso em relação à leitura, numeração, pronúncia e reconhecimento de alguns termos de saúde. As pesquisas de enfermagem analisadas evidenciaram lacunas no cuidado para avanço na participação do paciente nas tomadas de decisão, e os instrumentos utilizados para mensuração do letramento em saúde apresentam limitações, não existindo um padrão-ouro.

Descritores: Idoso. Alfabetização em saúde. Hipertensão. Pesquisa em enfermagem

\section{RESUMEN}

El objetivo fue analizar investigaciones de enfermería cuanto a los instrumentos utilizados para evaluar el letramiento en salud de ancianos hipertensos. Se trata de una revisión integradora realizada en las bases de datos LILACS, PubMed, CINAHL, Scopus y Cochrane, en junio de 2013, con artículos de investigación completos disponibles electrónicamente y que evaluaron el letramiento en salud de ancianos con hipertensión. Se seleccionaron ocho estudios para análisis y cuatro instrumentos diferentes fueron utilizados en las búsquedas. Los instrumentos fueron el resultado de investigaciones metodológicas y tenían en común la evaluación de la capacidad de ancianos con relación a la lectura, números, pronunciación y reconocimiento de algunos términos en salud. Las investigaciones en enfermería analizadas evidenciaron deficiencias en la atención para el avanzo en la participación del paciente en la toma de decisiones y los instrumentos utilizados para medir el letramiento en salud presentan limitaciones, no existiendo un estándar oro. Descriptores: Anciano. Alfabetización en salud. Hipertensión. Investigación en enfermería. 


\section{DINTRODUCTION}

The process of aging has reached an international importance due to the significant reduction of mortality and fertility in the 20th century. This transition has impacted the health of the populations and the organization of healthcare systems in the world(1).

The risk of developing chronic diseases (CD) increases with $\operatorname{age}^{(2)}$, and Hypertension (HBP) is the most common $\mathrm{CD}$ among the elderly, the main risk factor for mortality and the second leading cause of disability adjusted life years in the world ${ }^{(3-4)}$. In Brazil, it is a prevalent disorder in more than $60 \%$ of the individuals aged over 65 years ${ }^{(5)}$.

Actions that may impact the treatment of HBP concern educational activities included in the list of practices of health promotion at all levels of complexity. As a health educator, the nurse plays a key role in enabling the elderly patients to better handle HBP, based on interventions that increase the level of involvement and empowerment of these individuals.

When performing interventions of an educational nature, nurses should be aware of the personal factors that may interfere with the therapeutic process, such as Health Literacy $(\mathrm{HL})$.

$\mathrm{HL}$ is defined as the capacity to obtain, process and understand basic health information and services required to make appropriate health decisions ${ }^{(6)}$.

In the case of elderly, there are age-related peculiarities that can compromise a person's ability to make the best decision about their treatment ${ }^{(7)}$. The limitations of health literacy in fighting HBP have been associated to poor performance in health care, scarce knowledge on the disease, poor medication adherence, poor compliance with prescribed medicines and ineffective blood pressure control (8-9).

The promotion of HL by nurses should be stimulated, because in order to achieve better health outcomes, hypertensive elderly individuals need to adopt a healthy lifestyle and use wisely the healthcare services available, and make decisions that improve their health condition.

It is believed that in their assessment of the $\mathrm{HL}$ of elderly patients with $\mathrm{HBP}$, the nurses can make inferences about the degree to which these patients are able to understand and appropriately use received and/or shared health information, in order to achieve the desired therapeutic outcomes by actively participating in decision making.

Therefore, the following question has arisen: which instruments are used in research conducted by nurses to assess health literacy in elderly with HBP?

Thus, the purpose of this study was to analyze the instruments used to assess the HL of elderly with HBP pub- lished in nursing research. The contribution of this study is the presentation of the relevant elements in nursing care of elderly with $\mathrm{HBP}$, with emphasis on $\mathrm{HL}$ assessment that involves knowledge, understanding and patient's involvement in the therapeutic process.

\section{METHODS}

This study was based on integrative literature review aimed to gather and summarize research findings on a specific theme or issue, in a systematic and orderly manner, thereby contributing to a deeper understanding of the investigated topic ${ }^{(10)}$.

In order to perform the current review, the following steps were covered: identification of the research question and purpose of the study, literature search, data assessment, data analysis and presentation ${ }^{(11)}$.

The following inclusion criteria were observed for the search and selection of publications: full original articles published by nurses in national and international journals on health literacy in elderly with HBP. Studies in which at least one of the authors was graduated in Nursing and/or were attached to Nursing Schools and indexed by at least one of the following databases were included: LILACS (Literatura Latino-Americana em Ciências de Saúde), PubMed, CINAHL (Cumulative Index to Nursing and Allied Health Literature), Scopus e Cochrane. When articles could not be directly accessed from the referred databases, the CAPES (Coordination of Higher Education Personnel) portal for periodicals was also considered a source of data, when published in Portuguese, English or Spanish; traceable with the use of controlled descriptors: healthy literacy, questionnaire, elderly, hypertension, according to the DeCS health terminology of the Virtual Health Library.

The descriptor nursing was not used in this review, because its use during the search for articles in databases with other descriptors implied the absence of results. Boolean operators were used to systematize the searches, as follows: healthy literacy and questionnaire and elderly and hypertension. Articles not electronically available in full text were excluded.

Data collection was performed in June 2013 based on an instrument elaborated by the researchers using Microsoft Office Excel 2007 software. The variables selected for analysis of each study were identification and methodological characteristics of the studies, instruments used to assess health literacy and levels of scientific evidence ${ }^{(12)}$.

The titles of the papers and the authors' affiliation institutions were carefully read for inclusion of the articles in the review, since we were seeking publications by nurses. 
Then, the title and the abstract of each study obtained were read for the identification of the guiding question. When the use of health literacy assessment tools could not be identified, the full-text article was read. The flowchart of the collection of articles from the databases and on their selection is shown below (Figure 1).

\section{RESULTS}

After careful reading and observation of inclusion and exclusion criteria, 1169 studies were identified, and of these, 8 articles were selected for analysis. None of the studies of the Cochrane database met the established inclusion criteria.

Of the eight articles analyzed, seven were published in North American states and one in an East Asian country. In 2011, we noticed an increase in the number of studies on $\mathrm{HL}$, and the authors of two studies with patients suffering Heart Failure (HF)(13-14) did not inform the percentage of patients with HBP (Chart 1).

The publications ${ }^{(13-14)}$ were maintained in this review because the scientific evidence corroborates the occurrence of HBP in the samples of the studies. Epidemiological evidence from the Framingham ${ }^{(15)}$ study, for example, demonstrated that individuals with Heart Failure (HF) are 2 to 4 times more likely to develop HBP, and this risk increases progressively with age. In the United States, country where the studies were conducted, HBP is the chronic disease that most affects American elderly and $\mathrm{HF}$ is the greatest public health problem ${ }^{(16)}$.

The studies were classified into levels of evidence ${ }^{(12)}$ as follows: five were classified in to level $V^{(13,17,18,20,22)}$, which corresponds to the evidence resulting from a single de- scriptive or qualitative study, and three into level $\|^{(14,19,21)}$, concerning the evidence from at least one well-designed randomized controlled trial.

The analyzed articles were distributed into five descriptive studies, two of which developed HL assessment instruments and applied them in elderly with hypertension ${ }^{(18,22)}$ and three controlled randomized trials that investigated the relationship between the level of $\mathrm{HL}$ and aspects related to hypertension or associated complications ${ }^{(14,19,21)}$. In the analyzed articles, three studies had experimental design.

Validated questionnaires were to assess $\mathrm{HL}$ in the studies, which are described in Table 1.

The Short-Test of Functional Health Literacy in Adults (S-TOFHLA) was used in three studies ${ }^{(13-14,19)}$. In the present study, the HL level of the patient with HBP was classified as inadequate, marginal and adequate. It is the short version of another instrument used to assess HL, the Test of Functional Health Literacy in Adults (TOFHLA), and goes beyond word recognition to assess the patient's ability to understand health information.

The short and long versions of the instrument (S-TOFH$L A$ and TOFHLA) are validated in English and Spanish(23-25). There is also a third version of the instrument called Brief Test of Functional Health Literacy, which uses the S-TOFHLA, though including four numeracy items that are not present in the short instrument ${ }^{(26)}$.

The S-TOFHLA instrument was translated into Portuguese in a study conducted in 2006-2007 in the city of São Paulo, SP. The instrument was considered appropriate to assess HL in the Brazilian population (27).

The Rapid Estimate of Adult Literacy in Medicine (REALM) was developed for use in adults, provides a quick estimate of the reading level of words commonly used in a medical

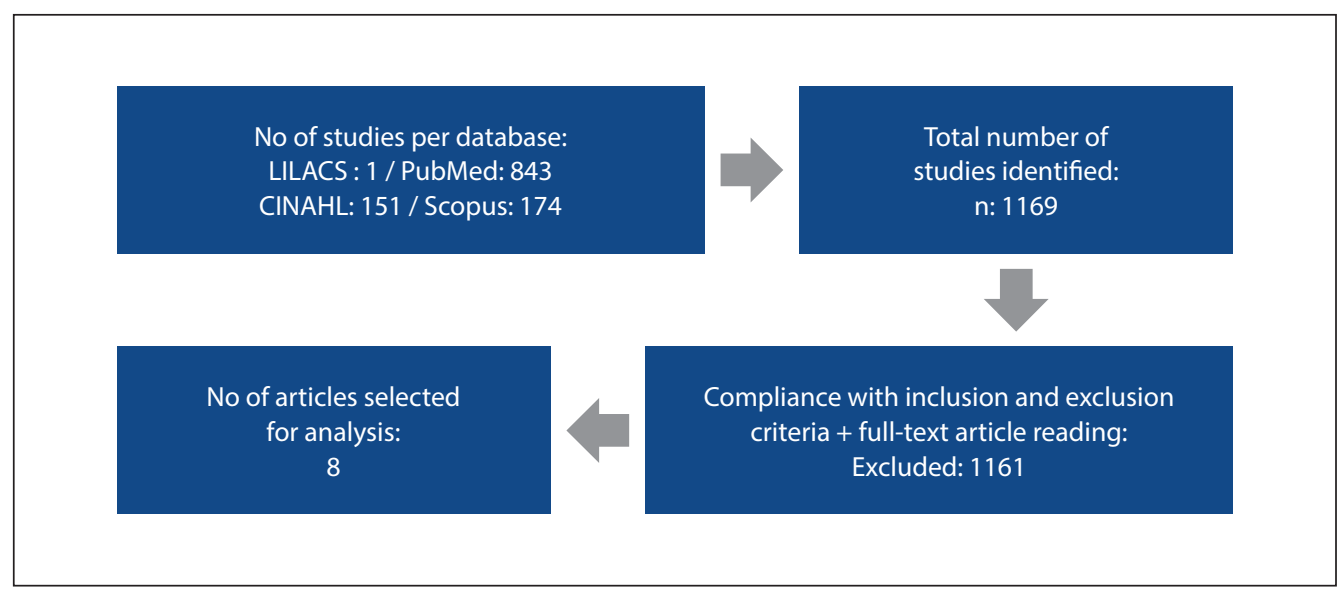

Figure 1. Flowchart of the articles selected at the databases. Fortaleza/ CE, 2013

Source: Research data. 
Machado ALG, Lima FET, Cavalcante TF, Araújo TL, Vieira NFC

\begin{tabular}{|c|c|c|c|c|c|}
\hline Title & Year & Country & Method & NE & Subjects \\
\hline $\begin{array}{l}\text { Beta Testing of a Network-Based Health Literacy } \\
\text { Program Tailored for Older Adults With Hypertension }{ }^{(17)}\end{array}$ & 2008 & $\begin{array}{l}\text { United } \\
\text { States }\end{array}$ & $\begin{array}{l}\text { Descriptive } \\
\text { study }\end{array}$ & VI & $\begin{array}{l}11 \text { elderly women } \\
\text { with HBP }\end{array}$ \\
\hline Testing health literacy skills in older Korean adults ${ }^{(18)}$ & 2009 & $\begin{array}{l}\text { South } \\
\text { Korea }\end{array}$ & $\begin{array}{l}\text { Methodological } \\
\text { study }\end{array}$ & $\mathrm{VI}$ & $\begin{array}{l}411 \text { elderly, } \\
53.1 \% \text { with HBP }\end{array}$ \\
\hline $\begin{array}{l}\text { Relationship Between Literacy, Knowledge, Self-Care } \\
\text { Behaviors, and Heart Failure-Related Quality of Life } \\
\text { Among Patients With Heart Failure }{ }^{(19)}\end{array}$ & 2011 & $\begin{array}{l}\text { United } \\
\text { States }\end{array}$ & $\begin{array}{l}\text { Randomized } \\
\text { clinical trial }\end{array}$ & ॥ & $\begin{array}{l}605 \text { adults } \\
\text { with } \mathrm{HF}, 85 \% \\
\text { hypertensive }\end{array}$ \\
\hline $\begin{array}{l}\text { Development and Results of a Kidney Disease } \\
\text { Knowledge Survey Given to Patients With CKD }\end{array}$ & 2011 & $\begin{array}{l}\text { United } \\
\text { States }\end{array}$ & $\begin{array}{l}\text { Descriptive } \\
\text { study }\end{array}$ & $\mathrm{VI}$ & $\begin{array}{l}401 \text { adults } \\
\text { with CKD, 86\% } \\
\text { hypertensive }\end{array}$ \\
\hline Assessing health literacy in heart failure patients ${ }^{(14)}$ & 2011 & $\begin{array}{l}\text { United } \\
\text { States }\end{array}$ & $\begin{array}{l}\text { Randomized } \\
\text { clinical trial }\end{array}$ & II & $\begin{array}{l}612 \text { adults with } \\
\text { HF, mean age of } \\
66 \text { years }\end{array}$ \\
\hline $\begin{array}{l}\text { Reducing adverse self-medication behaviors in older } \\
\text { adults with hypertension: results of an e-health clinical } \\
\text { efficacy trial(21) }\end{array}$ & 2011 & $\begin{array}{l}\text { United } \\
\text { States }\end{array}$ & $\begin{array}{l}\text { Randomized } \\
\text { clinical trial }\end{array}$ & $\|$ & $\begin{array}{l}160 \text { elderly with } \\
\text { HBP }\end{array}$ \\
\hline $\begin{array}{l}\text { Adequate health literacy is associated with higher } \\
\text { heart failure knowledge and self care confidence in } \\
\text { hospitalized patients }{ }^{(13)}\end{array}$ & 2011 & $\begin{array}{l}\text { United } \\
\text { States }\end{array}$ & $\begin{array}{l}\text { Descriptive } \\
\text { study }\end{array}$ & VI & $\begin{array}{l}95 \text { adults with } \\
\text { HF, mean age of } \\
59 \text { years }\end{array}$ \\
\hline $\begin{array}{l}\text { Development and Validation of the High Blood Pres- } \\
\text { sure-Focused Health Literacy Scale }{ }^{(22)}\end{array}$ & 2012 & $\begin{array}{l}\text { United } \\
\text { States }\end{array}$ & $\begin{array}{l}\text { Methodological } \\
\text { study }\end{array}$ & $\mathrm{VI}$ & $\begin{array}{l}440 \text { elderly with } \\
\text { HBP }\end{array}$ \\
\hline
\end{tabular}

Chart 1. General characteristics of the analyzed studies. Fortaleza/CE, 2013.

Source: Research data.

LE: Level of Evidence; HBP: High Blood Pressure; HF: Heart Failure; CKD: Chronic Kidney Disease.

Table 1. Description of the instruments used to assess health literacy in elderly with hypertension. Fortaleza CE, 2013.

\begin{tabular}{|c|c|c|c|}
\hline Instrument & Assessed aspects/ Rating of health literacy & $\begin{array}{l}\text { Length of time } \\
\text { of application } \\
\text { (minutes) }\end{array}$ & $\begin{array}{l}\text { Validated for } \\
\text { the Brazilian } \\
\text { population }\end{array}$ \\
\hline S-TOFHLA* & $\begin{array}{l}\text { Reading comprehension ( } 36 \text { items) } \\
\text { Classification: inadequate (0-16); marginal (17-22); adequate (23- } \\
\text { 36) }\end{array}$ & $7-12$ & Yes \\
\hline REALM $^{* *}$ & $\begin{array}{l}\text { Ability to recognize and pronounce health-related words/terms } \\
\text { (66 items) } \\
\text { Classification: converted into reading levels (0-9) }\end{array}$ & 3 & Yes \\
\hline$H B P-H L S^{* * *}$ & $\begin{array}{l}\text { Ability to read and pronounce words related to hypertension and } \\
\text { its treatment ( } 30 \text { items) and functional literacy ( } 7 \text { items) } \\
\text { Classification: mastery of reading/pronunciation (correct/incor- } \\
\text { rect, ranging from 0-30), mastery of functional literacy (correct/in- } \\
\text { correct, ranging from 0-13). }\end{array}$ & $10-15$ & No \\
\hline$K H L S^{* * * *}$ & $\begin{array}{l}\text { Abilities: reading and numeracy (13 items) and recognition of } \\
\text { health-related words ( } 11 \text { items). } \\
\text { Classification: cutoff points established to distinguish } \mathrm{HL} \text { levels. }\end{array}$ & $15-20$ & No \\
\hline
\end{tabular}

Source: Research data.

* Short-Test of Functional Health Literacy in Adults; ** Rapid Estimate of Adult Literacy in Medicine; *** High Blood Pressure - Health Literacy Scale; **** Korean Health Literacy Scale

104 Rev Gaúcha Enferm. 2014 dez;35(4):101-7. 
environment and involves only the recognition of words and not the understanding of the individuals. The test was present in three studies ${ }^{(17,20-21)}$ and consists in simple words organized in two columns containing words with one or two syllables and with three or more syllables. The instrument is validated in English ${ }^{(28)}$, Spanish ${ }^{(29)}$ (The Short Assessment of Health Literacy for Spanish speaking Adults-SAHLSA) and Portuguese ${ }^{(30)}$ (The Short Assessment of Health Literacy for Portuguese-speaking Adults-SAHLPA).

The researchers have explored more precise measures to determine $\mathrm{HL}$, with application in more specific health contexts, which have wide user acceptance and can be used by health professionals and researchers for practical and scientific purposes. Therefore, some measures were developed in the past few years to access $\mathrm{HL}$ in specific clinical contexts, e.g. in HBP.

Thus, for example, an instrument for assessing HL specifically in hypertensive individuals was developed, the High Blood Pressure-Health Literacy Scale (HBP-HLS). The scale consists in the assessment of HL dimensions: reading and pronunciation of words related to hypertension and its treatment and functional literacy, this last dimension being described as the use of instruction to perform a given task ${ }^{(22)}$.

For the creation of the scale, the authors modified items from two other health literacy assessment instruments in order to make them more relevant for the use in people with hypertension. The modified instruments were the TOFHLA and the Newest Vital Sign (NVS) ${ }^{(31)}$, the latter consisting of nutritional information on ice cream labeling: six questions that assess the individual's ability to interpret nutritional information. HBP-LS used nutritional information on the label of ramen (a popular Korean instant noodle), since reducing sodium intake is a skill required for the control of blood pressure.

The final version of HBP-HLS adapted seven items of TOFHLA and six items of NVS, indicating excellent internal consistency of the items with coefficients of 0.88 and 0.89 , respectively. The test for clinical validation of the scale was conducted with elderly people, and the scale is validated in English (22).

Another instrument for measuring $\mathrm{HL}$ was developed for use with elderly Koreans in order to assess their ability to understand health information, the Korean Health Literacy Scale (KHLS). The scale has twenty-four items divided into ability to read, use numbers and recognize health-related words, containing short passages, images and charts with the multiple-choice format. The instrument is validated in Korean, and the classification of the results is based on the skill levels for $L S^{(18)}$. The internal consistency of the scale is
0.891 , with 0.843 for the items of reading and numeracy and 0.845 for the words related to health.

\section{DISCUSSION}

The use of HL for managing HBP is an important aspect of nursing care, since it may reorient nursing actions to patients' self-care needs. Studies of the World Health Organization and of public health agencies of the United States and Canada identified HL as a key factor for population health ${ }^{(32-33)}$.

A growing number of studies have explored the difference between the $\mathrm{HL}$ of people and their ability to adopt health behaviors effectively. In the countries where it has been investigated, inadequate $\mathrm{HL}$ is associated to poor quality and expensive health care services ${ }^{\left({ }^{(2)} \text {. }\right.}$

The present review identified four instruments used in nursing research to assess the HL of elderly with $\mathrm{HBP}$, namely: S-TOFHLA, REALM, HBP-HLS and KHLS. These tools result from methodological research aimed to assess user behavior beyond the empirical management of data obtained by the mere observation of the daily or usual behavior of the user(34).

All the instruments assessed the ability of elderly patients regarding the following aspects: reading, numera$c y$, pronunciation and recognition of some health words, which allowed comparison between their findings. It should be stressed that the results obtained with the use of the Korean scale KHLS cannot be compared to other $\mathrm{HL}$ measurements, because there are no instruments in Korean comparable to the tests available in English, such as REALM or TOFHLA ${ }^{(18)}$.

The prevalence of inadequate $\mathrm{HL}$ is higher among elderly, a phenomenon that can be explained in the populations who learn to read and write but do not acquire the competence of using reading and writing to engage with social practices. Elderly people with low HL may find it difficult to understand instructions on the use of drugs for HBP, and some studies show an association with inadequate literacy and health-related problems ${ }^{(8)}$.

A cross-sectional study recently conducted in Brazil revealed that $27 \%$ of Brazilian elderly reported being illiterate and $22 \%$ reported problems with basic reading and writing ${ }^{(27)}$. Another study that adapted a Portuguese version of the SAHLSA test, Spanish version based on REALM, found that of the 93 individuals assessed for understanding of medical prescriptions, $58.1 \%$ made at least one mistake and were considered to have inadequate $\mathrm{HL}^{(26)}$.

In the United States, a group of researchers that used S-THOFLA for people with HBP obtained a prevalence of 
inadequate $\mathrm{HL}$ of $30.3 \%$ and $8.2 \%$ of marginal $\mathrm{HL}^{(9)}$. Fewer years of schooling, as well as old age and greater number of years living with hypertension HBP were associated with inadequate abilities for $\mathrm{HL}$.

According to the analysis of the articles reviewed here, the HL of elderly with HBP has limitations, especially regarding the management of care and knowledge of the disease ${ }^{(13,19,20)}$. Thus, the referred $\mathrm{HL}$ assessment instruments are potential tools that can be used by nurses to identify the abilities of elderly patients regarding the search, understanding and use of health information to improve the management of hypertension.

Moreover, age was negatively correlated with $\mathrm{HL}^{(13,19,21)}$. The relationship of inadequate HL of elderly with unfavorable health behaviors and outcomes demonstrates the need to promote the involvement of nurse professionals with this vulnerable population that is at greater risk of adverse outcomes of HBP.

Being aware of the abilities that contribute to self-care practices by elderly patients, nurses can develop educational strategies that facilitate the communication, such as the use of more visual materials to make instructions more effective, since the elderly have lower HL and need to understand the relevant health information in order to make sound decisions ${ }^{(35)}$

\section{CONCLUSIONS}

The nursing studies analyzed revealed the gaps in care related to measures aimed to increase patient's involvement in decision-making, and the instruments used in health literacy assessment have limitations.

Although there are different tests to measure health literacy, there is no single instrument suitable for all contexts. Nevertheless, the results of their application can be compared, since they assess similar literacy aspects, such as reading, pronunciation and recognition of medical terms. Furthermore, the use of these tools can facilitate the communication between the professional and the elderly patient, contributing to the development of educational activities and materials.

Some limitations were detected in the instruments REALM and S-TOFHLA because they were restricted to medical terms and did not assess other skills required by literacy such as conceptual and cultural knowledge, speech, listening and writing.

Given the scarcity of Brazilian literature on the theme, we emphasize the importance of broadening the discussion on the assessment of health literacy by Brazilian nurses based on the development of studies aimed to construct and validate other health literacy assessment tools, or even to validate the instruments discussed in this review not yet validated for the Brazilian population.

For effective nursing care to hypertensive patients, we recommend the combination of the outcomes of studies on health literacy and clinical practice in hypertension, in order to improve the health outcome of assisted elderly users.

\section{REFERENCES}

1. Mendes EV. 0 cuidado das condiçôes crônicas na atenção primária à saúde: 0 imperativo da consolidação da estratégia da saúde da família. Brasília (DF); 2012.

2. Santos VCF, Kalsing A, Ruiz ENF, Roese A, Gerhardt TE. Perfil das internaçōes por doenças crônicas não-transmissíveis sensíveis à atenção primária em idosos da metade sul do RS. Rev Gaúcha Enferm. 2013;34(3):124-31.

3. Lopez AD, Mathers CD, Ezzati M, Jamison DT, Murray CJ. Global and regional burden of disease and risk factors, 2001: systematic analysis of population health data. Lancet. 2006;367(9524):1747-57.

4. Lawes $C M$, Vander Hoorn S, Rodgers A. Global burden of blood-pressure-related disease, 2001. Lancet. 2008:371(9623):1513-8.

5. Sociedade Brasileira de Cardiologia. VI Diretrizes Brasileiras de Hipertensão. Arq Bras Cardiol. 2010;95 Supl 1:1-51.

6. US Department of Health and Human Services. Health communication. In: US Department of Health and Human Services. Healthy people 2010. Washington: U.S. Government Printing Office; 2000. v. 1, p. 1-25.

7. Pinho MX, Custódio 0, Makdisse M. Incidência de depressão e fatores associados em idosos residentes na comunidade: revisão de literatura. Rev Bras Geriatr Gerontol. 2009;12(1):123-40.

8. Pandit AU, Tang JW, Bailey SC, Davis TC, Bocchini MV, Persell SD, et al. Education, literacy, and health: mediating effects on hypertension knowledge and control. Patient Educ Couns. 2009;75(3):381-5.

9. Osborn CY, Paasche-Orlow MK, Bailey SC, Wolf MS. The mechanisms linking health literacy to behavior and health status. Am I Health Behav. 2011;35(1):118-28.

10. Mendes KS, Silveira RCCP, Galvão MC. Revisão integrativa: método de pesquisa para a incorporação de evidências na saúde e na enfermagem. Texto Contexto Enferm. 2008;17(4):758-64.

11. Whittmore R, KnalfK. The integrative review: updated methodology. J Adv Nurs. 2005;52(5):546-53.

12. Melnyk BM, Fineout-Overholt E. Evidence-based practice in nursing and healthcare: a quide to best practice. Philadelphia: Lippincot Williams \& Wilkins; 2005.

13. Dennison CR, McEntee ML, Samuel L, Johnson BJ, Rotman S, Kielty A, et al. Adequate health literacy is associated with higher heart failure knowledge and self care confidence in hospitalized patients. J Cardiovasc Nurs. 2011;26(5):359-67.

14. Robinson S, Moser D, Pelter MM, Nesbitt T, Paul SM, Dracup K. Assessing health literacy in heart failure patients. J Card Fail. 2011;17(11):887-92.

15. Kannel WB. Incidence and epidemiology of heart failure. Heart Fail Rev. 2000;5(2):167-73.

16. Federal Interagency Forum on Aging-Related Statistics (US). Older Americans 2012: key indicators of well-being [Internet]. Washington: Government Printing Office; 2012 [cited 2014 Sept 02]. Available from: http://www.agingstats.gov/ agingstatsdotnet/main_site/default.aspx

17. Neafsey PJ, Anderson E, Peabody S, Lin CA, Strickler Z, Vaughn K. Beta testing of a network-based health literacy program tailored for older adults with hypertension. Comput Inform Nurs. 2008;26(6):311-9. 
18. Lee TW, Kang SJ, Lee HJ, Hyun SI. Testing health literacy skills in older Korean adults. Patient Educ Couns. 2009;75(3):302-7.

19. Macabasco-O'Connell A, DeWalt DA, Broucksou KA, Hawk V, Baker DW, Schillinger D, et al. Relationship between literacy, knowledge, self-care behaviors, and heart failure-related quality of life among patients with heart failure. J Gen Intern Med. 2011;26(9):979-86.

20. Wright JA, Wallston KA, Elasy TA, Ikizler TA, Cavanaugh KL. Development and results of a kidney disease knowledge survey given to patients with CKD. Am J Kidney Dis. 2011;57(3):387-95.

21. Neafsey PJ, M'Ilan CE, Ge M, Walsh SJ, Lin CA, Anderson E. Reducing adverse self-medication behaviors in older adults with hypertension: results of an e-health clinical efficacy trial. Ageing Int. 2011;36(2):159-91.

22. Kim MT, Song HJ, Han HR, Song Y, Nam S, Nquyen TH, et al. Development and validation of the high blood pressure-focused health literacy scale. Patient Educ Couns. 2012:87(2):165-70.

23. Baker DW, Williams MV, Parker RM, Gazmararian JA, Nurss J. Development of a brief test to measure functional health literacy. Patient Educ Couns. 1999;38(1):33-42.

24. Parker RM, Baker DW, Williams MV, Nurss JR. The test of functional health literacy in adults: a new instrument for measuring patients'literacy skills. J Gen Intern Med. 1995;10(10):537-41.

25. Rivero-Méndez M, Suárez E, Solís-Báez SS, Hernández G, Cordero W, Vázquez I, et al. Internal consistency of the Spanish Health Literacy Test (TOFHLA-SPR) for Puerto Rico. PR Health Sci J. 2010;29(1):49-53.

26. Nurss JR, Parker RM, Williams MV, Baker DW. Test of functional health literacy in adults. Hartfort: Peppercorn Books and Press; 1995.
27. Carthery-Goulart MT, Anghinah R, Areza-Fegyweres R, Bahia VS, Brucki SM, Damin $A$, et al . Performance of a Brazilian population on the test of functional health literacy in adults. Rev Saude Publica. 2009;43(4):631-8.

28. Davis TC, Long SW, Jackson RH, Mayeaux EJ, George RB, Murphy PW, et al. Rapid estimate of adult literacy in medicine: a shortened screening instrument. Fam Med. 1993;25(6):391-5.

29. Lee SY, Bender DE, Ruiz RE, Cho YI. Development of easy-to-use Spanish Health Literacy Test. Heath Serv Res. 2006;41(4 Pt 1):1392-412.

30. Apolinario D, Braga RC, Magaldi RM, Busse AL, Campora F, Brucki S, et al. Short assessment of health literacy for Portuguese-speaking adults. Rev Saude Publica. 2012;46(4):702-11.

31. Weiss BD, Mays MZ, Martz W, Castro KM, DeWalt DA, Pignone MP, et al. Quick assessment of literacy in primary care: the newest vital sign. Ann Fam Med. 2005;3(6):514-22.

32. World Health Organization (SZ). Health literacy and health behavior [Internet] 2011 [cited 2013 Mar 20]. Available from: www.who.int/healthpromotion/ conferences/7gchp/track2/en/

33. Public Health Agency Canada. The chief public health officer's report on the state of public health in Canada. Chapter 4: setting conditions for healthy aging [Internet] 2010 [cited 2013 Apr 10]. Available from: www.phac-aspc.gc.ca/ cphorsphc-respcacsp/2010/fr-rc/cphorsphc-respcacsp-07-eng.php.

34. Borges JWP, Moreira TM, Rodrigues MT, Oliveira CJ. Utilização de questionários validados para mensurar a adesão ao tratamento da hipertensão arterial: uma revisão integrativa. Rev Esc Enferm USP. 2012;46(2):487-94.

35. Passamai MPB, Sampaio HAC, Lima JWO. Letramento funcional em saúde de adultos no contexto do Sistema Único de Saúde. Fortaleza: EdUECE; 2013.

\section{Author's address:}

Ana Larissa Gomes Machado

Rua Dondon Feitosa, 35/501, Damas

60426-090, Fortaleza, CE

E-mail: analarissa2001@yahoo.com.br
Received: 22.02.2014

Approved: 06.10.2014 